\section{Analisis Literasi Keuangan, Perilaku Keuangan, Dan Pendapatan Terhadap Keputusan Investasi}

\author{
Ulfy Safryani ${ }^{1)}$, Alfida Aziz ${ }^{2)}$, Nunuk Triwahyuningtyas ${ }^{3)}$
kultas Ekonomi dan Bisnis, Universitas Pembangunan Nasional Veteran Jakarta \\ Ulfy Safryani ${ }^{1)}$, Alfida Aziz ${ }^{2)}$, Nunuk Triwahyuningtyas ${ }^{3)}$
Fakultas Ekonomi dan Bisnis, Universitas Pembangunan Nasional Veteran Jakarta \\ Email: ${ }^{1}$ ulfysaf@gmail.com, ${ }^{2}$ alfidaaziz61@gmail.com, ${ }^{3}$ nunukwowo@gmail.com
}

Financial Literacy,

Behavior, Income

and Investment

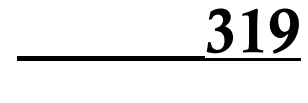

Submitted:

SEPTEMBER 2020

\section{ABSTRAK}

Penelitian ini merupakan penelitian kuantitatif yang memiliki tujuan untuk mengetahui pengaruh dari literasi keuangan, perilaku keuangan dan pendapatan terhadap keputusan investasi. Populasi pada penelitian ini adalah Dosen Tetap Fakultas Ekonomi dan Bisnis Universitas Pembangunan Nasional Veteran Jakarta. Sampel sebanyak 80 orang responden. Metode non probability sampling, purposive sampling. Pengumpulan data dilakukan dengan menyebarkan kuesioner kepada sampel yang telah ditentukan melalui google form. Teknik analisis data menggunakan metode analisis PLS (Partial Least Square) dengan software Smart PLS 3.0. Hasil penelitian ini menunjukkan bahwa: (1) Literasi keuangan memiliki pengaruh terhadap keputusan investasi dengan nilai koefisien jalur sebersar 0,455 ; (2) Perilaku keuangan tidak memiliki pengaruh signifikan terhadap keputusan investasi dengan nilai koefisien jalur sebersar 0,165; (3) Pendapatan memiliki pengaruh signifikan terhadap keputusan investasi dengan nilai koefisien jalur sebesar 0,337 .

Kata Kunci: Literasi Keuangan; Perilaku Keuanga; Pendapatan; Keputusan Investasi.

\begin{abstract}
Research is a quantitative study that has a purpose to know the influence of financial literacy, financial behaviour and income to investment decisions. The population in this research is the permanent lecturer Faculty of Economics and Business of National Development University Veteran Jakarta. Samples were taken as many as 80 respondents, with non probability sampling methods, purposive sampling. Data collection is done by spreading the questionnaire to the sample that has been determined through Google form. Data analysis techniques used are analysis methods PLS (Partial Least Square) with Smart software PLS 3.0. The results of this study show that: (1) Financial literacy has an influence on investment decisions with the value of the line coefficient of 0.455; (2) Financial behavior has no influence on investment decisions with the value of the line coefficient 0.165; (3) Revenue has an influence on investment decisions with a line coefficient value of 0.337 .
\end{abstract}

Keywords: Financial Literacy; Financial Behavior; Income; Investment Decisions.

\section{PENDAHULUAN}

Kegiatan mengelola keuangan harus dilakukan dengan cermat seiring dengan pesatnya perkembangan ekonomi di era globalisasi. Keputusan atas dana yang digunakan dapat dihasilkan dari kegiatan tersebut. Saat ini perlu memiliki pengetahuan serta wawasan terhadap pengelolaan keuangan. Semakin sering seseorang menghadapi serta intens mengahadapi permasalahan ekonomi, pengetahuan mengenai keuangan yang dimilikinya kemungkinan besar sehingga digunakan sebagai dasar pertimbangan yang baik dalam keputusan pengelolaan sumber keuangannya. Pengetahuan serta pemahaman harus dimiliki pada setiap individu, hal tersebut dapat memaksimalkan penggunaan

\section{Accepted: NOVEMBER 2020}


Financial Literacy, Behavior, Income and Investment instrumen-instrumen dan pruduk-produk financial yang ada sehingga keputusan yang tepat dapat dapat diambil oleh individu tersebut. Salah satunya adalah dengan melakukan kegiatan investasi yang dapat menaikan taraf hidup seseorang.

Investasi merupakan sebuah kegiatan dalam perekonomian dengan menanamkan modal secara langsung ataupun tidak langsung, sehinggal pemilik modal memiliki harapan akan mendapatkan keuntungan dari modal yang ditanamkan. Ada banyak sektor dalam investasi, diantaranya sektor rill, sektor perbankan, hingga pasar modal. Investasi sektor perbankan memiliki skala yang cenderung kecil pada risikonya, tingkat likuidasi yang tinggi dengan waktu jatuh tempo pendek, sedangkan pada pasar modal, dengan barang yang dijual berupa saham dan obligasi baik miliki perusahaan maupun pemerintah. Risiko yang tinggi ada pada investasi sektor pasar modal apabila dibandingkan dengan sektor lainnya, tetapi return (keuntungan) yang dihasilkan juga lebih tinggi dibantingkan sektor lainnya.

Perkembangan zaman saat ini menuntut setiap individu untuk mempunyai kesadaran akan pentingnya berinvestasi. Dengan kemampuan seseorang yang tinggi dalam mengelola keuangan maka akan sangat selektif dalam melakukan keputusan investasi. Berikut adalah data pertumbuhan jumlah Single Investor Identification (SID) tahun 20142018 di Indonesia.

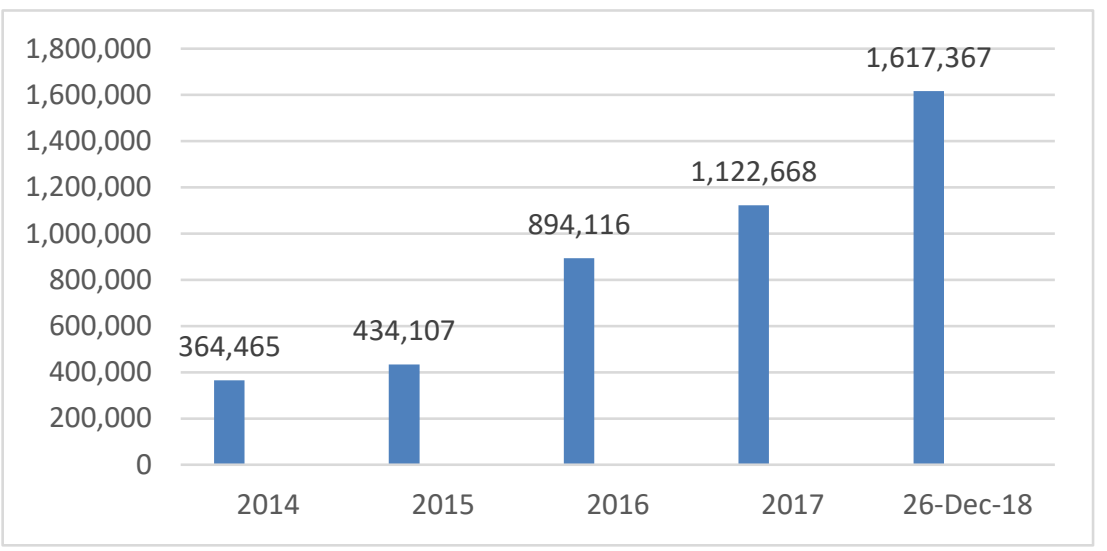

Sumber: data diolah (PT Kustodian Sentral Efek Indonesia 2018)

Gambar 1. Pertumbuhan Jumlah Single Investor Identification

Berdasarkan data diatas, terlihat bahwa kemauan masyarakat Indonesia untuk berinvestasi sangatlah besar. Dengan nilai 1.613 .165 yang menyatakan jumlah Single Investor Identification (SID), dimana nilai tersebut menggambarkan pertumbuhan sebesar $44 \%$. Nilai tersebut tercatat di KSEI dengan bentuk Surat Utang, Surat Berharga Negara (SBSN), Reksa Dana, Investor Saham dan Efek lainnya yang menjadi bagian dari jumlah Single Investor Identification (SID). Dengan rincian, aset Saham senilai 851.662 SID, kemudian nilai aset Reksan Dana sebesar 988.946 SID serta dengan nilai 195.119 SID komposisi Surat Berharga Negara. Pada 26 Desember 2018 jumlah aset yang ada di CBEST didominasi oleh investor lokal sebagai pemiliknya dengan angka persentase $54,71 \%$. Angka tersebut menunjukkan peningkatan yang terjadi dari tahun sebelumnya dari nilai 54,50\% pada kepemilikan lokal. Pria menjadi jenis kelamin yang mendominasi sebesar 59,13\% pada data demografi investor di Indonesia, berusia 21-30 tahun sebesar $39,72 \%$, dengan persentase $58,27 \%$ sebagai pegawai swasta sebagai status pekerjaannya dan $51,42 \%$ sarjana sebagai pendidikan terakhirnya. Kenaikan jumlah investor tersebut adalah hasil dari campur tangan pemerintah yang terus mengedukasi masyarakat, salah satunya dengan cara meningkatkan literasi keuangan.

Literasi keuangan dimanfaatkan untuk mengetahui layanan, suatu lembaga serta produk jasa keuangan, dan juga didalamnya tentang upaya meningkatkan kesejahteraan seseorang melalui perubahan yang berkaitan dengan sikap serta perilaku keuangan seseorang. Berikut adalah tabel persentase yang menunjukkan Literasi Keuangan di negara-negara Asia Tenggara. 
Berdasarkan data diatas terlihat bahwa persentase literasi keuangan Indonesia berada pada kondisi yang cukup rendah, apabila disandingkan pada beberapa Negara di ASEAN lainnya yaitu sebesar 29\%. Sedangkan, literasi keuangan pada negara Malaysia sebersar $66 \%$, di Thailand sebesar $73 \%$ dan di Singapura sebesar $98 \%$.

Tabel 1. Persentase Literasi Keuangan Negara-Negara Di Asia Tenggara

\begin{tabular}{cc}
\hline Negara & Persentase (\%) \\
\hline Indonesia & 29 \\
\hline Malaysia & 66 \\
\hline Thailand & 73 \\
\hline Singapura & 98 \\
\hline Sumber: data diolah (Otoritas Jasa Keuangan 2016)
\end{tabular}

Hasil survei tahun 2016 menunjukkan tingkat literasi keuangan sebesar 29,7\% yang dimiliki oleh Indonesia melalui Survei Nasional Literasi dan Inklusi Keuangan diselenggarakan oleh Otoritas Jasa Keuangan. Pernyataan Sondang Martha selaku Kepala Departemen Literasi dan Inklusi Keuangan OJK yang dimuat dalam www.financial.bisnis.com mengulas "terdapat sekitar 70 orang dari 100 orang yang mempunyai produk keuagan, sementara hanya terdapat 30 orang yang mampu memahami terkait keuangan," menurutnya kurangnya literasi keuangan pada masyarkat berdampak pada kehidupan sekarang dan masa depan, hal tersebut dapat menimbulkan dampak yang buruk. Seorang investor saat melakukan kegiatan investasi tidaklah hanya melihat dari perkiraan atas prospek dalam intrumen investasinya tapi faktor psikologi juga menentukan keputusan investasi yang akan diambil. Banyak pihak yang mengatakan perna besar dalam berinvestasi dilandasi faktor psikologi seorang investor. Perilaku keuangan (behavior finance) atau tingkah laku menjadi dasar analisis investasi dengan menggunakan ilmu psikolog dan juga ilmu keuangan (Fitriarianti, 2018).

Berdasarkan riset yang dilakukan GoBear Indonesia dalam riset yang bertajuk GoBear Financial Health Index (FHI) yang diulas pada www.keuangan.kontan.co.id. Riset tersebut melibatkan responden dari sejumlah negara di Asia Tenggara, menunjukkan bahwa kesadaran masyarakat Indonesia terkait perencanaan keuangan masih rendah. Hasil dari studi FHI menyatakan bahwa belum terencananya sebuah perencanaan keuangan di usia 35 tahun dan baru memulai perencanaan pensiun di usia 41 tahun. Penelitian tersebut juga menunjukkan bahwa adanya rasa aman pada masyarakat Indonesia dengan gambaran nilai 7,5 dari skala 1-10 secara keuangan, kenyataannya apabila sumber pendapatannya hilang hanya sebesar 37\% dari masyarakat Indonesia yang memiliki tabungan untuk mencukupi kebutuhan hidup lebih dari 6 bulan. Dari hasil riset tersebut dapat diketahui jika perilaku keuangan maasyarakat Indonesia masih sangat kurang baik, dengan perencana keuangan mereka masih sangat rendah. Faktor lain yang dapat mempengaruhi seseorang dengan keputusan investasi adalah pendapatan. Pendapatan salah satu indikator yang menjadi tolak ukur kesejahteraan seseorang. Pendapatan seseorang ialah senilai penghasilan seseorang yang didapatkan melalui kurun waktu tertentu baik harian, mingguan, bahkan bulanan atas prestasi kerjanya. Dengan pendapatan dengan nilai yang lebih dari individu, perilaku keuangan yang lebih bertanggung jawab terlihat pada individu tersebut, hal ini sebab kepemilikan dana lebih menjadi dasar perilaku keuangan dalam mengelola keuangannya (Kholilah \& Iramani, 2013).

Salah satu pekerjaan dengan tingkat keuangan yang cukup baik dan memiliki pendidikan yang baik adalah dosen. Menurut (Kumala \& Susanti, 2019). Pendidikan yang semakin tinggi yang ditempuh seseorang akan memperluas pengetahuan mereka di berbagai bidang, termasuk dalam bidang keuangan hingga paham atas keputusan yang diambil untuk investasi. Dosen merupakan pengajar yang memiliki pengetahuan dan pendidikan yang tinggi, oleh karena itu dosen seharusnya semakin baik dalam mengelola keuangannya. Untuk mendukung fenomena yang ada, peneliti melakukan pra survei dengan menyebar kuesioner dengan media google form ke sebanyak 5 Dosen Tetap FEB Universitas Pembangunan Nasional Veteran Jakarta, khususnnya di Fakultas Ekonomi
Financial Literacy, Behavior, Income and Investment 
Financial Literacy, Behavior, Income and Investment dan Bisnis. Untuk mengetahui litersai keuangan, perilaku keuangna dan pendapatan terhadap keputuasn investasi pada Dosen Tetap FEB Universitas Pembangunan Nasional Veteran Jakarta.

Dari hasil pra survei ditemukan fenomena bahwa keputusan investasi yang dilakukan Dosen Tetap Fakultas Ekonomi dan Bisnis cukup baik, diliat dari jawaban responden dimana pada pernyataan pada indikator-indikator keputusan investasi responden banyak yang menyetujui pernyataan tersebut, menunjukkan bahwa keputusan investasi mereka sudah cukup baik. Namun tingginya keputusan investasi para Dosen Tetap Universitas Pembangunan Nasional Veteran, yang fokus penelitiannya pada Fakultas Ekonomi dan Bisnis tidak diikuti dengan literasi keuangan yang tinggi pula, dilihat dari jawaban pada pernyataan tentang literasi keuangan yang kurang baik, karana masih ada yang memilih netral, bahkan tidak menyetujui pernyataan pada indikator literasi keuangan tersebut. Fenomena selanjutnya adalah pada variabel perilaku keuangan menunjukkan jawaban dari responden masih kurang baik, dilihat dari jawaban responden mengenai perencanaan keuangan dan penganggaran keuangan hampir sebagian dari responden netral dan juga tidak menyetuji pernyataan tersebut.

Dalam penelitian (Rasuma Putri \& Rahyuda, 2017) mengatakan tingkat literasi keuangan pada keputusan invetasi perorangan berpengaruh positif, sedangakan pada keputusan investasi invidual, pendapatan memiliki pengaruh negatif. Berbeda dengan penelitian (Pradikasi, 2018) mengatakan illusion of control dan risk perseption serta literasi keuangan tidak berpengaruh terhadap keputusan investasi dan overconfidance dan risk tolarance berpengaruh terhadap keputusan investasi. Penelitian yang dilakukan (Dewi \& Purbawangsa, 2018) mengatakan positif pengaruh literasi keuangan dan pendapatan pada keputusan investasi, namun secara positif tidak perpengaruh masa bekerja pada perilaku keputusan investasi. Selanjutnya dalam penelitian (Fitriarianti, 2018) mengatakan hubungan yang tidak saling mempengaruhi dari literasi keuangan dengan keputusan berinvestasi, namun berpengaruh pada hubungan perilaku keuangan dan pendapatan pada keputusan berinvestai.

Penelitian ini dilakukan untuk mengetahui pengaruh dari literasi keuangan, perilaku keuangan dan pendapatan terhadap keputusan investasi. Maka perumusan masalah pada penelitian ini adalah apakah literasi keuangan, perilaku keuangan, dan pendapatan berpengaruh terhadap keputusan investasi.

\section{Hipotesis}

$\mathrm{H}_{1}$ : Literasi keuangan mempunyai pengaruh yang positif pada keputusan investasi.

$\mathrm{H}_{2}$ : Perilaku keungan mempunyai pengaruh yang positif pada keputusan investasi.

$\mathrm{H}_{3}$ : Pendapatan mempunyai pengaruh yang positif pada keputusan investasi.

\section{METODE PENELITIAN}

\section{Definisi Operasional}

a. Keputusan Investasi (Y)

Keputusan Investasi mempunyai makna yaitu suatu tindakan yang diambil seseorang pada masa sekarang yang diproyeksikan di masa mendatang guna mendapatkan keuntungan.

b. Literasi Keuangan (X1)

Literasi keuangan ialah pengetahuan tentang keuangan dalam aspek lembaga keuangan dan konsep keuangan secara menyeluruh, serta kemampuan dalam memanfaatkan produk keuangan dan mengelola keuangan pribadi dalam rangka membuat keputusan jangka pendek maupun jangka panjang.

c. Perilaku Keuangan (X2)

Perilaku keuangan ialah bentuk penggabungan dari aspek kemampuan finansial dan kemampuan psikologis seseorang dalam mengelola dan memanfaatkan sumber daya keuangannya sebagai landasan dalam pengambilan keputusan untuk kebutuhan sehari-hari dan perencanaan keuangan dimasa yang akan datang, ataupun kegiatan bisnis yang dimiliki. 
d. Pendapatan (X3)

Pendapatan ialah seluruh penghasilan yang berasal dari gaji perusahaan, hasil penjualan, investasi ataupun sumber lainnya yang berbentuk uang, barang, ataupun kepuasan psikologis.

\section{Pengukuran Variabel}

Tabel 2. Pengukuran Variabel

\begin{tabular}{lll}
\hline Variabel & Indikator Skala & Skala Pengukuran \\
\hline \multirow{3}{*}{ Keputusan Investasi $(\mathrm{Y})$} & Rate of return & Likert \\
\cline { 2 - 3 } & Return of risk & Likert \\
\cline { 2 - 3 } & Hubungan return dan risk & Likert \\
\hline \multirow{3}{*}{ Literasi Keuangan $\left(\mathrm{X}_{1}\right)$} & Pengetahuan keuangan dasar & Likert \\
\cline { 2 - 3 } & Tabungan dan pinjaman & Likert \\
\cline { 2 - 3 } & Asuransi & Likert \\
\cline { 2 - 3 } & Investasi & Likert \\
\hline \multirow{3}{*}{ Perilaku Keuangan $\left(\mathrm{X}_{2}\right)$} & Perencanaan Keuangan & Likert \\
\cline { 2 - 3 } & Penganggaran Keuangan & Likert \\
\cline { 2 - 3 } & Pengelolaan Keuangan & Likert \\
\hline \multirow{2}{*}{ Pendapatan $\left(\mathrm{X}_{3}\right)$} & Penyimpanan Keuangan & Likert \\
\cline { 2 - 3 } & Gaji/Upah & Likert \\
\hline
\end{tabular}

Sumber : data diolah

\section{Populasi}

Populasi penelitian ini adalah Dosen Tetap di Universitas Pembangunan Nasional Veteran Jakarta Fakultas Ekonomi dan Bisnis.

\section{Sampel}

Penelitian ini mempergunakan teknik pengambilan sampel nonprobability sampling dengan model purposive sampling. Teknik non-probability sampling merupakan suatu cara terkait pengambilan sampel pada sebuah populasi dengan pemberian peluang atau kesempatan yang berbeda terhadap masing-masing unsur dari populasi yang kemudian akan dijadikan. Purposive sampling dipilih sebagai metode pengambilan sampel, di mana metode ini dilandasi beberapa pertimbangan tertentu dalam pemilihan sampel yang akan di ambil dan diguanakan dalam penelitian untuk upaya tertentu yang ingin dicapai. Dengan menggunakan rumus slovin sampel yang digunakan adalah 80 responden

Teknik Pengumpulan Data

Tabel 3. Skala Likert

\begin{tabular}{ccc}
\hline Bobot & Pertanyaan & Pengertian \\
\hline 5 & SS & Sangat Setuju \\
\hline 4 & S & Setuju \\
\hline 3 & CS & Cukup Setuju \\
\hline 2 & TS & Tidak Setuju \\
\hline 1 & STS & Sangat Tidak Setuju \\
\hline
\end{tabular}

Sumber : Sugiyono (2016, hlm.93)

Jenis data yang digunakan dalam penelitian ini adalah data primer, data diperoleh secara langsung melalui pembagian kuesioner kepada 80 Dosen tetap FEB Universitas Pembangunan Nasional Veteran Jakarta. Skala yang digunakan adalah skala likert.

\section{Teknik Analisa Data}

Teknik analisa data yang digunakan dalam penelitian ini adalah analisis data deskriptif dan analisa data dengan software PLS.

\section{Analisis Data Deskriptif}

Persepsi responden tersebut digambarkan menggunakan teknik skoring, teknik skoring yang digunakan terdiri dari peringkat berupa angka dan membentuk jawaban dari 1 sampai 5.
Financial Literacy, Behavior, Income and Investment 
Financial Literacy,

Behavior, Income

and Investment
Tabel 4. Interpretasi Nilai Presentase Responden

\begin{tabular}{cc}
\hline Nilai Indeks & Interpretasi \\
\hline $16-36$ & Rendah \\
\hline $37-58$ & Sedang \\
\hline $59-80$ & Tinggi
\end{tabular}

Sumber : Ferdinand (2014)

324

Data yang didapatkan dari hasil penelitian akan diolah menggunakan teknik analisis data yaitu Partial Least Square (PLS). Partial Least Square (PLS) merupakan metode analisis yang cukup kuat karena didasari dengan banyak asumsi, data yang digunakan tidak harus berdistribusi normal multivariate (indikator yang diliputi dengan skala kategori, ordinal hingga rasio dapat digunakan ada model yang sama), sampel tidak harus besar, bisa memuat 30 sampai 100 sampel dan dapat digunakan untuk menjelaskan ada atau tidaknya hubungan antara variabel laten (terukur secara tidak langsung).

\section{Kerangka Model Penelitian}

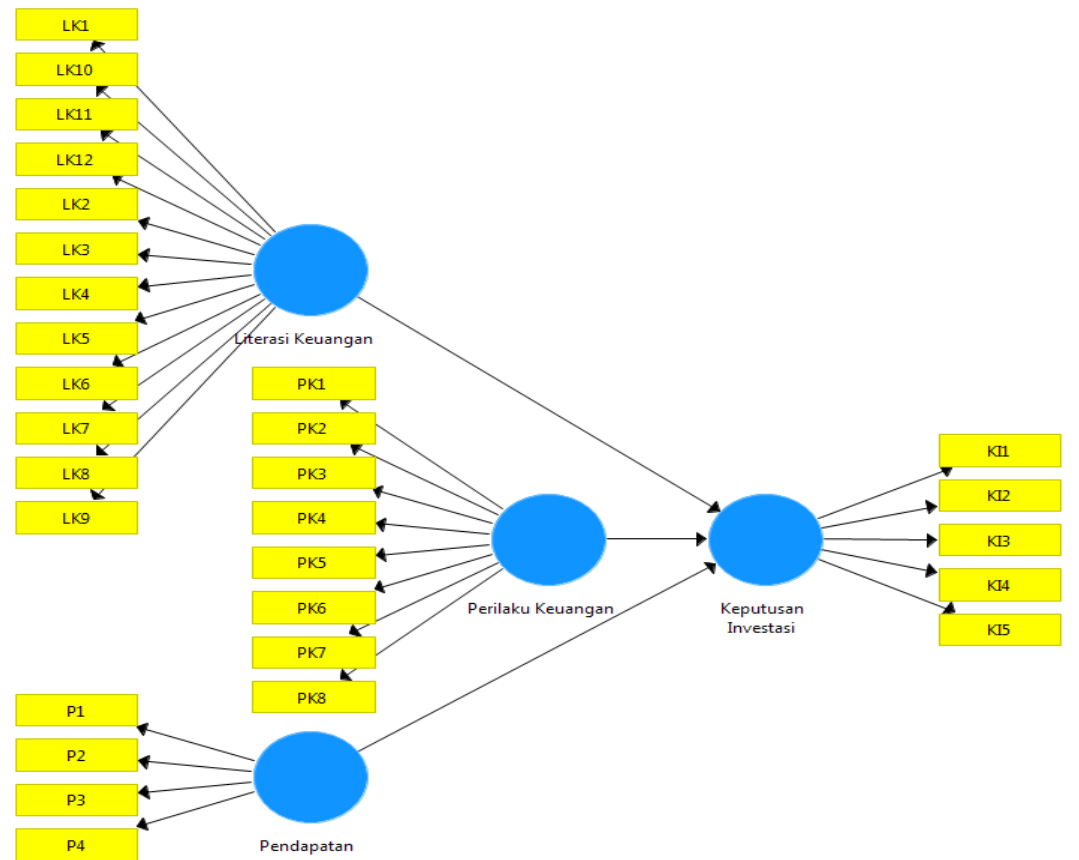

Sumber : data diolah melalui SmartPLS

Gambar 3. Kerangka Model Penelitian

\section{HASIL DAN PEMBAHASAN \\ Deskripsi Data Responden}

Karakteristik Responden Berdasarkan Jenis Kelamin terdapat responden yang berjenis kelamin Laki-laki sebanyak 26 responden (32,5\%), sedangkan responden yang berjenis kelamin Perempuan sebanyak 54 responden (67,5\%). Karakteristik Responden Berdasarkan Usia terdapat 10 responden untuk usia 25 - 30 tahun (12,5\%), untuk usia 31 - 40 tahun sebanyak 16 responden (20\%), untuk usia 41 - 50 tahun sebanyak 11 responden $(13,75 \%)$ dan usia $>50$ tahun sebanyak 43 responden (53,75\%). Karakteristik Responden Berdasarkan Tingkat Pendidikan terdapat responden S2 sebanyak 70 responden (87,5\%), dan S3 sebanyak 10 responden (12,5\%). Karakteristik Responden Berdasarkan Lama Bekerja terdapat responden berdasarkan lama bekerja 1-3 tahun sebanyak 9 responden (11,25\%), 3-5 tahun sebanyak 4 responden (5\%), dan $>5$ tahun sebanyak 67 responden (83,75\%). Karakteristik Responden Berdasarkan Pendapatan Perbulan terdapat responden berdasarkan pendapatan perbulan yaitu : pendapatan perbulan dibawah 3 juta berjumlah 1 responden $(1,25 \%)$, untuk pendapatan perbulan 3-5 juta berjumlah 16 responden (20\%), untuk pendapatan perbulan 5-7 juta bejumlah 18 responden $(22,5 \%)$, untuk pendapatan perbulan $7-10$ juta berjumlah 31 responden $(38,75 \%)$, dan untuk 
pendapatan diatas 10 juta berjumlah 14 responden (17,5\%). Karakteristik Responden Berdasarkan Produk Investasi Yang Dimiliki terdapat responden yang memiliki produk investasi yaitu: saham berjumlah 12 responden (15\%), untuk Properti 34 responden (42,5\%), untuk Emas bejumlah 43 responden (53,75\%) dan untuk Simpanan Pihak Ketiga berjumlah 80 responden (100\%). Karakteristik Responden Berdasarkan Jenis Investasi Simpanan Pihak Ketiga Yang Dimikili terdapat responden berdasarkan jenis investasi simpanan pihak ketiga yaitu: deposito 35 responden $(43,75 \%)$, dan untuk tabungan bejumlah 74 responden (92,5\%). Karakteristik Responden Berdasarkan Lama Pengalaman Investasi terdapat responden berdasarkan lama pengalaman investasi menjadi 4 kelompok yaitu: 1-2 tahun sebanyak 3 responden (3,75\%), 2-3 tahun sebanyak 5 responden $(6,25 \%), 3-4$ tahun sebanyak 5 responden $(6,25 \%)$, dan $>4$ tahun sebanyak 67 responden $(83,75 \%)$.

\section{Analisis Data Deskriptif}

Berikut adalah hasil dari perhitungan indeks jawaban yang diberikan oleh responden mengenai tanggapan terhadap butir-butir pertanyaan yang telah diajukan melalui kuesioner penelitian :

a. Analisis Indeks Jawaban Responden pada Veriabel Literasi Keuangan

Tabel 5. Hasil Jawaban Responden Terhadap Variabel Lterasi Keuangan

\begin{tabular}{ccccccc}
\hline Literasi & 1 & 2 & 3 & 4 & 5 & \multirow{2}{*}{ Indeks (\%) } \\
\cline { 2 - 5 } Keuangan $\left(\mathrm{X}_{1}\right)$ & $\mathrm{F}$ & $\mathrm{F}$ & $\mathrm{F}$ & $\mathrm{F}$ & $\mathrm{F}$ & \\
\hline LK1 & 0 & 1 & 2 & 36 & 41 & 71,4 \\
\hline LK2 & 0 & 1 & 0 & 28 & 51 & 73,8 \\
\hline LK3 & 0 & 0 & 3 & 37 & 40 & 71,4 \\
\hline LK4 & 0 & 2 & 6 & 30 & 42 & 70,4 \\
\hline LK5 & 2 & 3 & 1 & 30 & 44 & 70,2 \\
\hline LK6 & 2 & 1 & 5 & 30 & 42 & 69,8 \\
\hline LK7 & 2 & 2 & 3 & 36 & 37 & 68,8 \\
\hline LK8 & 4 & 1 & 4 & 35 & 36 & 67,6 \\
\hline LK9 & 2 & 0 & 2 & 37 & 39 & 70,2 \\
\hline LK10 & 0 & 0 & 2 & 38 & 40 & 71,6 \\
\hline LK11 & 0 & 1 & 6 & 39 & 34 & 69,2 \\
\hline LK12 & 0 & 0 & 3 & 45 & 32 & 69,8 \\
\hline & Rata - Rata Total Indeks & & & $\mathbf{7 0 , 3 5}$ \\
\hline
\end{tabular}

Sumber : data diolah

Pada variabel ini nilai indeks tertinggi terdapat pada butir pertanyaan LK10 (Investasi merupakan penanaman modal untuk jangka panjang dengan harapan mendapatkan keuntungan dimasa mendatang) sebesar $71,6 \%$ dan memiliki hasil frekuensi terbanyak dengan skor 5 jawaban responden (Sangat Setuju) sebanyak 40 responden. Sedangkan nilai indeks terendah pada butir pertanyaan LK8 (Asuransi merupakan salah satu instrument mengendalikan risiko yang melakuakn pengaluhan risiko ke pihak lain) sebesar 67,6\% dan memiliki hasil frekuensi jawaban terbanyak dengan skor 5 (Sangat Setuju) sebanyak 36 responden. Adapun rata - rata indeks variabel sikap keuangan sebesar $70,35 \%$ berada pada kategori yang tinggi. Sehingga dapat disimpulkan responden memiliki persepsi pada setiap item literasi keuangan yang tinggi.

b. Analisis Indeks Jawaban Responden Terhadap Perilaku Keuangan

Butir pertanyaan PK7 memiliki nilai indeks tertinggi sebesar 70,2\% (Saya menyiapkan uang untuk kebutuhan tidak terduga di masa yang akan datang) dan memiliki hasil frekuensi jawaban responden paling banyak menjawab skor 5 (Sangat Setuju) sebanyak 39 responden. Sedangkan nilai indeks terendah pada butir pertanyaan PK4 (Saya mencatat pengeluaran (harian, mingguan, bulanan, dll)) sebesar $58 \%$ dan memiliki hasil frekuensi jawaban responden paling banyak menjawab skor 4 (Setuju) sebanyak 35 responden. Adapun $64,6 \%$ sebagai rata - rata indeks variabel perilaku keuangan yang
Financial Literacy, Behavior, Income and Investment 
Financial Literacy, Behavior, Income and Investment

326 tinggi kategorinya. Sehingga dapat disimpulkan responden memiliki persepsi pada setiap item perilaku keuangan yang tinggi.

Tabel 6. Hasil Tanggapan Responden akan Variabel Perilaku Keuangan

\begin{tabular}{ccccccc}
\hline \multirow{2}{*}{ Perilaku Keuangan $\left(\mathrm{X}_{2}\right)$} & 1 & 2 & 3 & 4 & 5 & \multirow{2}{*}{ Indeks (\%) } \\
\cline { 2 - 6 } & $\mathrm{F}$ & $\mathrm{F}$ & $\mathrm{F}$ & $\mathrm{F}$ & $\mathrm{F}$ & \\
\hline PK1 & 1 & 6 & 8 & 37 & 28 & 65 \\
\hline PK2 & 1 & 8 & 10 & 45 & 16 & 61,4 \\
\hline PK3 & 1 & 4 & 11 & 49 & 15 & 62,6 \\
\hline PK4 & 1 & 10 & 19 & 35 & 15 & 58,6 \\
\hline PK5 & 0 & 4 & 8 & 52 & 16 & 64 \\
\hline PK6 & 0 & 3 & 2 & 45 & 30 & 68,4 \\
\hline PK7 & 1 & 2 & 1 & 37 & 39 & 70,2 \\
\hline PK8 & 1 & 2 & 7 & 43 & 27 & 66,6 \\
\hline & \multicolumn{5}{c}{ Rata - Rata Total Indeks } & \\
\hline
\end{tabular}

Sumber : data diolah

c. Analisis Indeks Jawaban Responden Terhadap Pendapatan

Tabel 7. Hasil Tanggapan Responden akan Variabel Pendapatan

\begin{tabular}{ccccccc}
\hline \multirow{2}{*}{ Pendapatan (X3) } & 1 & 2 & 3 & 4 & 5 & \multirow{2}{*}{ Indeks (\%) } \\
\cline { 2 - 6 } & $\mathrm{F}$ & $\mathrm{F}$ & $\mathrm{F}$ & $\mathrm{F}$ & $\mathrm{F}$ & \\
\hline P1 & 0 & 6 & 7 & 43 & 24 & 65 \\
\hline P2 & 0 & 1 & 6 & 54 & 19 & 66,2 \\
\hline P3 & 3 & 12 & 16 & 31 & 18 & 57,8 \\
\hline P4 & 1 & 10 & 24 & 31 & 14 & 57,4 \\
\hline \multicolumn{7}{c}{ Rata-Rata Total Indeks } \\
\hline
\end{tabular}

Sumber : data diolah

Pertanyaan P2 memiliki nilai indeks yang tinggi (Saya menyisihkan gaji yang saya terima untuk berinvestasi) sebesar $66,2 \%$ dan memiliki hasil frekuensi jawaban responden paling banyak menjawab skor 4 (Setuju) sebanyak 54 responden. Sedangkan nilai indeks terendah pada butir pertanyaan P4 (Bonus yang saya dapatkan, saya gunakan untuk berinvestasi) sebesar $57,4 \%$ dan memiliki hasil frekuensi jawaban responden paling banyak menjawab skor 4 (Setuju) sebanyak 31 responden. Adapun rata - rata indeks variabel pendapatan sebesar $61,6 \%$ berada pada kategori yang tinggi. Sehingga dapat disimpulkan tinggi bentukan persepsi responden pada item pertanyaan variabel pendapatan.

d. Analisis Indeks Jawaban Responden Terhadap Keputusan Investasi Tabel 8. Hasil Tanggapan Responden akan Variabel Keputusan Investasi

\begin{tabular}{ccccccc}
\hline \multirow{2}{*}{$\begin{array}{c}\text { Keputusan Investasi } \\
(\mathrm{Y})\end{array}$} & 1 & 2 & 3 & 4 & 5 & \multirow{2}{*}{ Indeks (\%) } \\
\cline { 2 - 6 } KI1 & $\mathrm{F}$ & $\mathrm{F}$ & $\mathrm{F}$ & $\mathrm{F}$ & $\mathrm{F}$ & \\
\hline $\mathrm{KI} 2$ & 0 & 3 & 6 & 37 & 34 & 68,4 \\
\hline $\mathrm{KI} 3$ & 0 & 1 & 5 & 47 & 27 & 68 \\
\hline $\mathrm{KI} 4$ & 0 & 4 & 3 & 39 & 34 & 68,6 \\
\hline KI5 & 0 & 0 & 4 & 32 & 44 & 72 \\
\hline \multicolumn{7}{c}{ Rata - Rata Total Indeks } \\
\hline
\end{tabular}

Sumber : data diolah

Hasil tabel 8. diperoleh hasil penilaian variabel pada pertanyaan keputusan investasi. Nilai tertinggi ada pada butir pertanyaan KI4 (Saya mempelajari terlebih dahulu risiko apa yang akan diterima sebelum melakukan kegiatan investasi) sebesar $72 \%$ dan memiliki hasil frekuensi jawaban responden paling banyak menjawab skor 5 (Sangat Setuju) sebanyak 44 responden. Sedangkan nilai indeks terendah pada butir pertanyaan KI2 (Saya dapat menganalisa return (tingkat pengembalian modal) dari investasi yang dilakukan) sebesar $68 \%$ dan memiliki hasil frekuensi jawaban responden paling banyak menjawab skor 4 (Setuju) sebanyak 47 responden. Adapun rata - rata indeks variabel sikap keuangan sebesar $69,08 \%$ berada pada kategori yang tinggi. Sehingga dapat 
disimpulkan tingginya persepsi responden tinggi pada item pertanyaan variabel Financial Literacy, keputusan investasi.

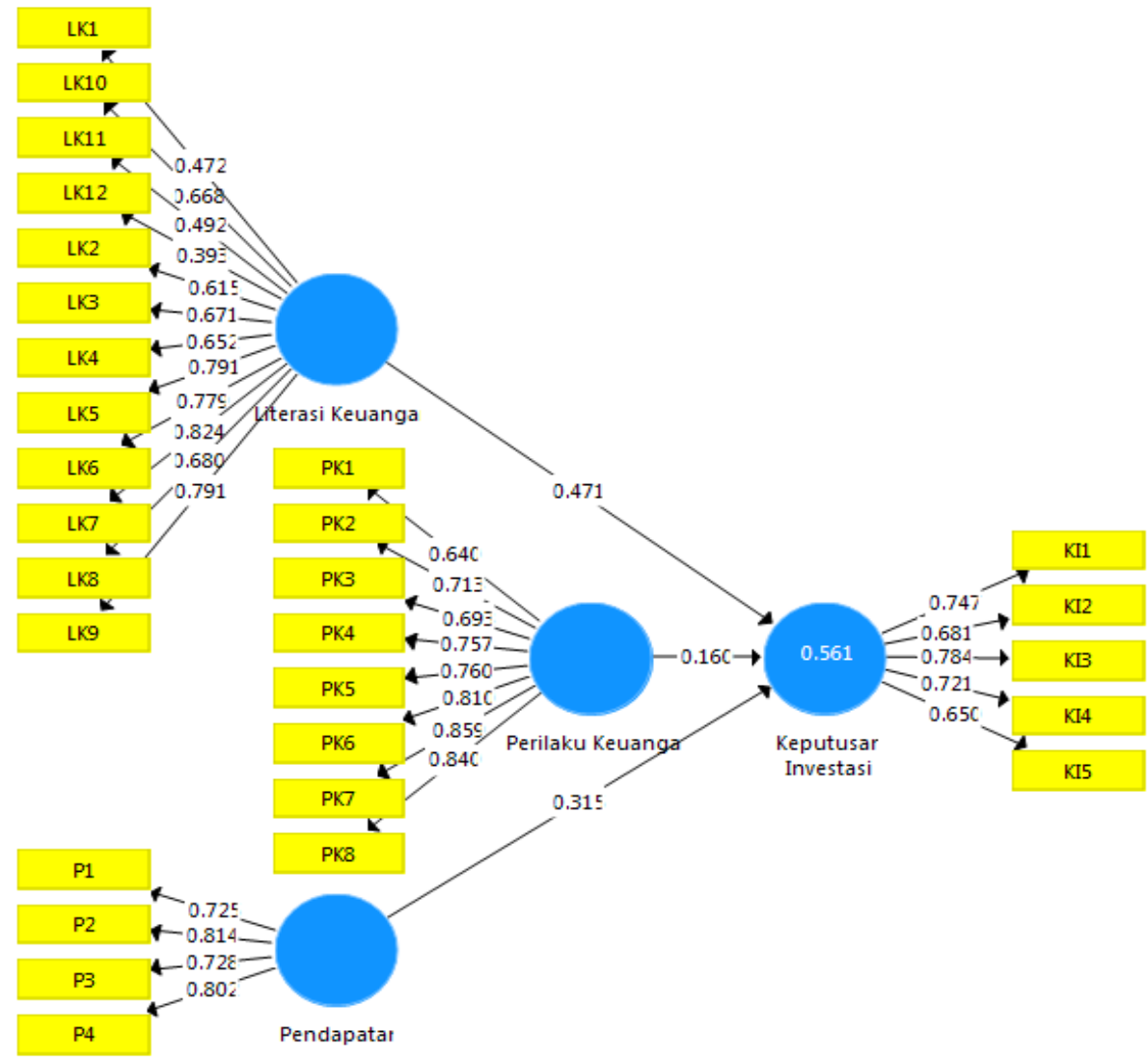

Sumber : hasil Output SmartPLS 3.0

Gambar 4. Outer Model

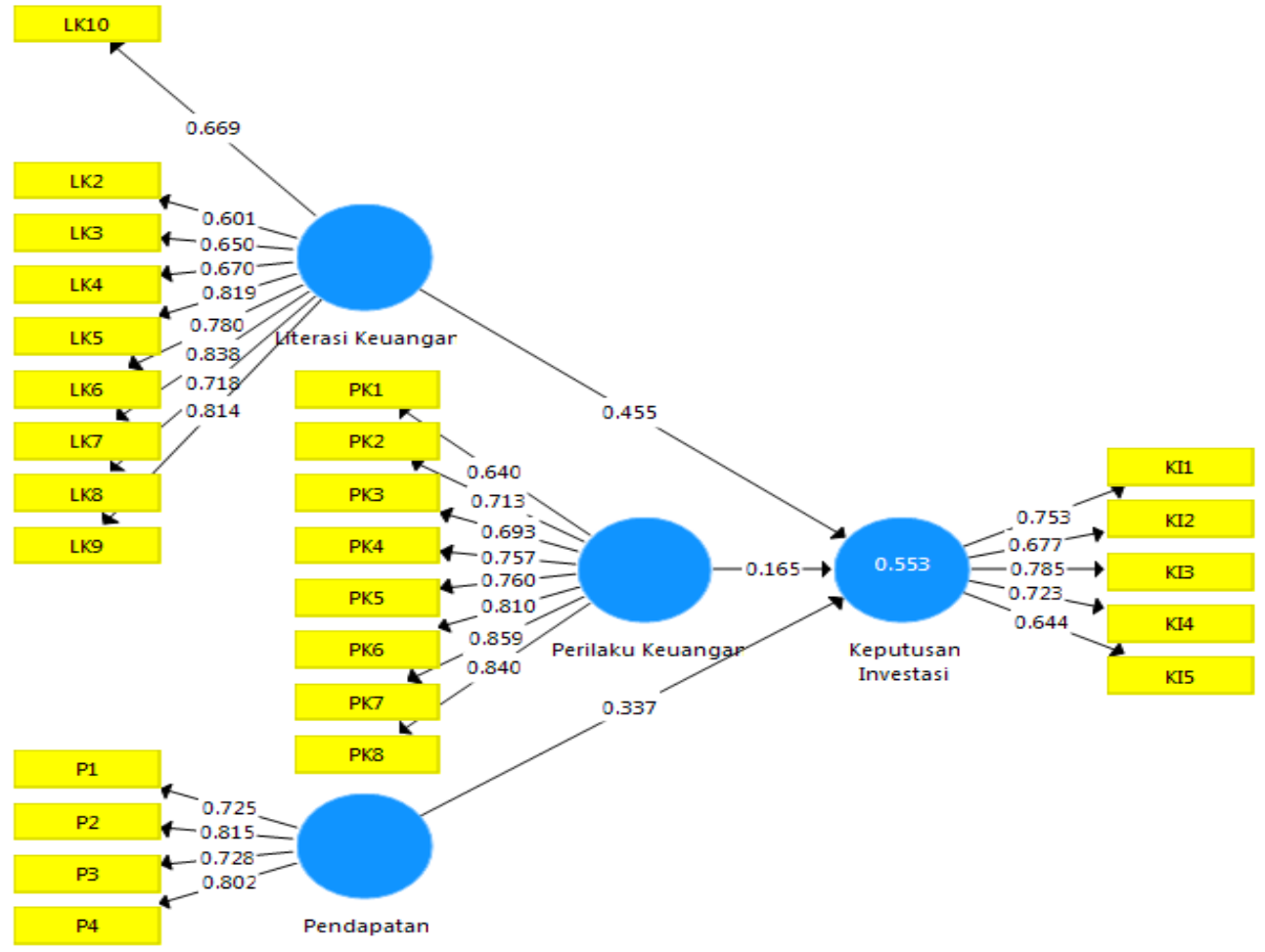

Sumber : Hasil Output SmartPLS 3.0

Gambar 5. Outer Model Setelah Re-estimasi 
Financial Literacy, Behavior, Income and Investment

\section{Analisis Data dan Uji Hipotesis \\ Model Pengukuran (Outer Model)}

Untuk validitas variabel keputusan investasi perilaku keuangan dan pendapatan serta pada indikator tidak menunjukkan kendala karena hasil menunjukkan lebih besar dari 0,5 . Hadil pada literasi keuangan menunjukkan hasil yang lebih kecil dari 0,5 yaitu, LK1 yang memiliki nilai 0,472 , LK11 yang memiliki nilai 0,492 , LK12 yang memiliki nilai 0,393 sehingga hasil respon tersebuh dihapus dan tidak dipergunakan lagi.

Dari hasil re-estimasi pada Gambar 5. dapat dinyatakan bahwa seluruh instrumen setiap indikator sudagh valid dengan pemenuhan seluruh syarat, dikarenakan seluruh nilai korelasi yaitu nilai factor loading lebih dari 0.50 .

Uji Validitas Diskriminan

Tabel 9. Average Variance Extracted (AVE)

\begin{tabular}{ll}
\hline \multicolumn{1}{c}{ Keterangan } & AVE \\
\hline Keputusan Investasi (Y) & 0.516 \\
\hline Literasi Keuangan (X1) & 0.538 \\
\hline Pendapatan (X3) & 0.590 \\
\hline Perilaku Keuangan (X2) & 0.581 \\
\hline
\end{tabular}

Sumber : Hasil Output SmartPLS 3.0

Nilai AVE diatas 0,50 dan dianggap valid. Nilai tertinggi AVE yaitu pada variabel pendapatan yaitu 0,590 sedangkan untuk nilai terendah AVE yaitu pada variabel keputusan investasi yaitu 0,516 .

Uji Reliabilitas PLS

Tabel 10. Composite Reliability dan Cronbach's Alpha

\begin{tabular}{lcc}
\hline \multicolumn{1}{c}{ Variabel } & Composite Reliability & Cronbach's Alpha \\
\hline Keputusan Investasi (Y) & 0.841 & 0.763 \\
\hline Literasi Keuangan (X1) & 0.912 & 0.891 \\
\hline Pendapatan (X3) & 0.852 & 0.777 \\
\hline Perilaku Keuangan (X2) & 0.917 & 0.896 \\
\hline
\end{tabular}

Sumber: Hasil Output SmartPLS 3.0

Nilai dari setiap variabel dalam composite reliability dan cronbach's alpha lebih dari 0,70 , maka jawaban yang diberikan responden terhadap setiap butir pertanyaan bersifat konsisten dan stabil sehingga menghasilkan nilai reliabilitas yang baik atau reliabel.

\section{R-Square}

Tabel 11. R-Square

\begin{tabular}{cc}
\hline Variabel & R-Square \\
\hline Keputusan Investasi $(\mathrm{Y})$ & 0.553 \\
\hline
\end{tabular}

Sumber : Hasil Output SmartPLS 3.0

Diketahui hasil besarnya nilai R-Square $\left(\mathrm{R}^{2}\right)$ keputusan investasi yaitu sebesar 0,553. Maka dapat diasumsikan bahwa literasi keuangan, perilaku keuangan dan pendapatan berkontribusi sebesar 55,3\% terhadap keputusan investasi dan sisanya sebesar 44,7\% menjelaskan bahwa adaya pengaruh pada keputusan investasi yang oleh variabel atau faktor lain seperti sikap keuangan dan faktor demografi turut andil dalam mempengaruhinya.

\section{Uji Hipotesis dan Uji T-Statistik}

Uji t-statistik digunakan peneliti untuk mengetahui apakah variabel independen (X) secara individual mempengaruhi variabel dependen $(\mathrm{Y})$. $\mathrm{T}$ tabel $=1,992$ hasil sisioan rumus $\mathrm{df}=\mathrm{n}-\mathrm{k}$ atau $\mathrm{df}=80-4=76$, kemudian menghubungkn level signifikansi sebesar 0,05 atau $5 \%$.

Hasil original sample pada variabel literasi keuanagn sesuai tabel di atas sebesar 0,455, pendapatan 0,337 , dan perilaku keuangan sebesar 0,165 . Hasil original sample untuk ketiga variabel tersebut adalah positif yang berarti hubungan literasi keuangan, perilaku keuangan dan pendapatan pada keputusan investasi adalah positif dalam hal ini hasil original sample tidak ada yang negatif. Tabel 12. di atas menunjukkan bahwa variabel literasi keuangan memiliki t-hitung 3,669 > ttabel 1,992 dan nilai signifikansi (P Values) 
$0,000<0,05$ dan menunjukkan Ho ditolak dan Ha diterima. Maka literasi keuangan disimpulkan berpengaruh positif dan signifikan tehadap keputusan investasi.

Tabel 12. Path Coefficients

\begin{tabular}{lccccc}
\hline \multicolumn{1}{c}{ Construct } & $\begin{array}{c}\text { Original } \\
\text { Sample (O) }\end{array}$ & $\begin{array}{c}\text { Sample } \\
\text { Mean } \\
(\mathbf{M})\end{array}$ & $\begin{array}{c}\text { Standart } \\
\text { Deviation } \\
(\text { STDEV) }\end{array}$ & $\begin{array}{c}\text { T Statistic } \\
(\mid \text { O/STDEV |) }\end{array}$ & P Values \\
\hline $\begin{array}{l}\text { Literasi Keuangan -> } \\
\text { Keputusan Investas }\end{array}$ & 0.455 & 0.476 & 0.124 & 3.669 & 0.000 \\
\hline $\begin{array}{l}\text { Pendapatan -> Keputusan } \\
\text { Investasi }\end{array}$ & 0.337 & 0.325 & 0.084 & 4.027 & 0,000 \\
\hline $\begin{array}{l}\text { Perilaku Keuangan-> } \\
\text { Keputusan Investasi }\end{array}$ & 0.165 & 0.167 & 0.120 & 1.373 & 0.171 \\
\hline
\end{tabular}

Sumber: Hasil Output PLS 3.0

Tabel 12. di atas menunjukkan variabel pendapatan memiliki t-hitung 4,027 > ttabel 1,992 dan nilai signifikansi (P Values) $0,000<0,05$ yang menunjukkan Ho ditolak dan $\mathrm{Ha}$ diterima. Oleh karena itu, pendapatan berpengaruh signifikan positif tehadap keputusan investasi. Tabel 12. di atas menunjukkan bahwa variabel perilaku keuangan memiliki thitung 1,373 < ttabel 1,992 dan nilai signifikansi ( $\mathrm{P}$ Values) $0,171>0,05$ yang menunjukkan Ho diterima dan Ha ditolak. Maka disimpulkan perilaku keuangan tidak berpengaruh terhadap terhadap keputusan investasi.

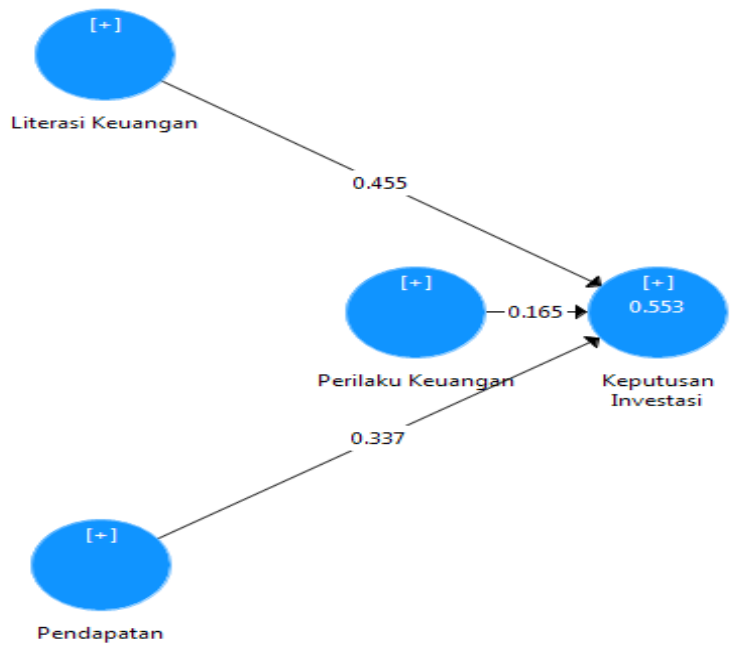

Sumber : Hasil Output SmartPLS 3.0

\section{PEMBAHASAN}

Gambar 6. Inner Model

\section{Pengaruh Literasi Keuangan terhadap Keputusan Investasi}

Berdasarkan hasil penelitian yang telah dilakukan antara keterikatan kedua variabel, menunjukan nilai koefisien jalur literasi keuangan terhadap keputusan investasi sebesar 0,455 dan uji t-statistik menunjukan nilai thitung 3,669 > ttabel 1,992 dan nilai signifikan $P$ Values) sebesar $0,000<0,05$. Hal tersebut menunjukan variabel literasi keuangan berpengaruh secara signifikan terhadap keputusan investasi pada dosen tetap FEB UPNVJ. Artinya dalam hal ini indikator-indikator yang terdapat pada literasi keuangan sudah memberikan kontribusi yang cukup sebagai perannya untuk mempengaruhi keputusan investasi. Dengan demikian dapat diartikan literasi keuangan memiliki pengaruh positif secara signifikan pada keputusan investasi atau dalam kata lain H1 diterima. Besar pengaruh literasi keuangan terhadap keputusan investasi adalah sebesar $45,5 \%$. Hasil ini mendukung dan sejalan dengan hipotesis penelitian.

Dalam penelitian ini, diketahui mayoritas Dosen Tetap FEB UPNVJ atas kepemilikan dasar pengetahuan keuangan, tabungan dan pinjaman, investasi , dan asuransi yang cukup baik. Sesuai dengan hasil tersebut dimana objek pada penelitian ini dengan tingkat pendidikan Dosen UPNVJ Tetap khusnya pada FEB yang tinggi yaitu S2 dan S3, diikuti dengan pengetahuan mereka akan keuangan yang baik. Oleh karena itu, literasi
Financial Literacy, Behavior, Income and Investment 
Financial Literacy, Behavior, Income and Investment keuangan berpengaruh positif terhadap keputusan invetsasi, artinya semakin tinggi literasi keuangan dosen maka akan semakin baik pula keputusan investasi yang dilakukannya. Tingkat literasi keuangan penting karena individu kemungkinan dalam pengambilan sebuah keputusan investasi. Dengan memiliki tingkat litersai keuangan yang baik, individu cenderung akan lebih bijaksana dan pandai dalam mengelola aset yang dimilikinya sehingga dapat memberikan timbal-balik yang bermanfaat dalam mendukung keuangan individu.

Penelitian ini sejalan dengan Putri dan Hamidi (2019), Welly dkk (2016),. Putri dan Rahyuda (2017), Kumala (2019), Dewi dan Purbawangsa (2018), Faidah (2019), dan Pratiwi dkk (2020) yang dalam penelitiannya menyimpulkan bahwa variabel litersai keuangan memiliki pengaruh signifikan terhadap keputuasm investasi. Maka hasil penelitian ini sesuai dengan hipotesis yang telah dibuat yaitu literasi keuangan berpengaruh secara signifikan terhadap keputusan investasi Dosen Tetap FEB UPNVJ yang artinya $\mathrm{H} 1$ diterima.

\section{Pengaruh Perilaku Keuangan terhadap Keputusan Investasi}

Berdasarkan hasil penelitian yang telah dilakukan antara keterikatan kedua variabel, menunjukan nilai koefisien jalur perilaku keuangan terhadap keputusan investasi sebesar 0,467 dan uji t-statistik menunjukan nilai thitung $1.373<$ ttabel 1,992 dan nilai signifikan ( $P$ Values) sebesar $0.171>0,05$. Hal tersebut menunjukan bahwa variabel perilaku keuangan tidak berpengaruh terhadap keputusan investasi pada dosen tetap FEB UPNVJ. Artinya dalam hal ini indikator-indikator yang terdapat pada perilaku keuangan yaitu Perencanaan Keuangan, Penganggaran Keuangan, Pengelolaan Keuangan dan Penyimpanan Keuangan tidak memberikan kontribusi yang besar dalam perannya untuk mempengaruhi keputusan investasi. Dengan demikian dapat diartikan perilaku keuangan tidak berpengaruh terhadap keputusan investasi atau dalam kata lain $\mathrm{H} 2$ ditolak. Besar pengaruh perilaku keuangan terhadap keputusan investasi adalah sebesar 16,5\%. Hasil penelitian ini tidak mendukung hipotesis awal yang diajukan pada penelitian ini yaitu perilaku keuangan berpengaruh positif terhadap keputusan.

Perilaku keuangan dosen tidak terpengaruh pada keputusan investasi para Dosen Tetap FEB UPNVJ. Dapat dilihat dari hasil jawaban responden pada butir pernyataan PK2, PK3, dan PK4 dimana dari jawabannya responden hanya beberapa orang yang menjawab sangat setuju sehingga dapat diketahui bahwa perilaku keuangan para responden masih belum maksimal, sehingga dapat diketahui perilaku keuangan dosen tidak mempengaruh dalam keputusan investasi pada Dosen Tetap FEB UPNVJ. Maka hasil penelitian ini tidak sesuai dengan hipotesis yang telah dibuat yaitu perilaku keuangan tidak berpengaruh secara signifikan terhadap keputusan investasi Dosen Tetap FEB UPNVJ yang artinya $\mathrm{H} 2$ ditolak.

\section{Pengaruh Pendapatan terhadap Keputusan Investasi}

Berdasarkan hasil penelitian yang telah dilakukan antara keterikatan kedua variabel, menunjukan nilai koefisien jalur pendapatan terhadap keputusan investasi sebesar 0,337 dan uji t-statistik menunjukan nila thitung $4.027>$ ttabel 1,992 dan nilai signifikan $(P$ Values) sebesar $0,000<0,05$ ini menunjukan bahwa variabel pendapatan berpengaruh signifikan positif terhadap keputusan dosen tetap FEB UPNVJ dalam melakukan keputusan untuk investasi. Artinya dalam hal ini indikator-indikator yang terdapat pada pendapatan yaitu gaji/upah dan bonus/komisi sudah memberikan kontribusi yang cukup besar sebagai perannya untuk mempengaruhi keputusan investasi. Dengan demikian dapat diartikan pendapatan berpengaruh signifikan positif terhadap keputusan investasi atau dalam kata lain H3 diterima. Besar pengaruh pendapatan terhadap keputusan investasi adalah sebesar 33,7\%. Hasil ini mendukung dan sejalan dengan hipotesis awal yang diajukan pada penelitian ini.

Hasil penelitian ini menunjukkan mayoritas pendapatan diterima oleh mayoritas Dosen Tetap FEB UPNVJ sesuai dengan apa yang dilakukan dalam pekerjaan serta dalam satu bulan dapat menjadi pemenuh kebutuhan hidupnya. Pendapatan yang diterima berada pada kisaran $\mathrm{Rp} 7.000 .001$ hingga $\mathrm{Rp}$ 10.000.000. Namun ada juga yang berpenghasilan dibawah $\mathrm{Rp} 3.000 .000$, diantara $\mathrm{Rp} 3.000 .001$ sampai dengan $\mathrm{Rp}$ 
7.000.000. Serta diatas Rp.10.000.000. Dari data diatas dapat dikatakan bahwa Dosen Tetap Fakultas Ekonomi dan Bisnis Universitas Pembangunan Nasional Veteran Jakarta banyak yang memiliki pendapatan yang tinggi dan hal tersebut berpengaruh terhadap keputusan investasi paraa dosen. Rendah, sedang, dan tingginya pendapatan seseorang berpengaruh terhadap keputusan investasi yang diambilnya. Dengan kata lain semakin tinggi pendapatannya maka semakin baik keputusan investasi orang tersebut. Sehingga dapat dikatan bahwa dosen yang memiliki pendapatan yang lebih tingi akan memiliki kesempatan untuk berinvestasi lebih baik dibandingkan dosen yang memiliki pendapatan lebih rendah. Seperti halnya, dengan pendapatan yang lebih tinggi dapat memberikan kesempatan dosen untuk berinvestasi karena kemungkinan masih ada surplus dari pendapatannya. Pendapatan seseorang mempunyai pengaruh terhadap pengelolaan keuangan pribadinya, semakin banyak pendapatan mereka maka semakin besar pertimbangannya untuk melakukan keputusan berinvestasi.

Hasil penelitian ini sejalan dengan Fitrianti (2018), Dewi dan Purbawangsa (2018) yang dalam penelitiannya menyimpulkan bahwa variabel pendapatan memiliki pengaruh signifikan terhadap keputusan investasi.Maka hasil penelitian ini sesuai dengan hipotesis yang telah dibuat yaitu pendapatan berpengaruh secara signifikan terhadap keputusan investasi Dosen Tetap FEB UPNVJ Jakarta yang artinya H3 diterima.

\section{PENUTUP}

Melalui penelitian ini, peneliti bermaksud untuk mencari tahu terkait pengaruh dari literasi keuangan, perilaku keuanga, dan pendapatan pada keputusan investasi dari Dosen Tetap FEB Universitas Pembangunan Nasional Veteran Jakarta. Berdasarkan hasil olah data beserta analisis dan pembahasan yang sudah dilaksanakan pada penelitian ini, sehingga dapat ditarik kesimpulan yaitu:

a Literasi keuangan memiliki pengaruh yang positif terhadap keputusan investasi para Dosen Tetap Fakultas Ekonomi dan Bisnis Universitas Pembangunan Nasional Veteran Jakarta.

b. Perilaku keuangan tidak mempunyai pengaruh terhadap keputusan investasi para Dosen Tetap Fakultas Ekonomi dan Bisnis Universitas Pembangunan Nasional Veteran Jakarta.

c. Pendapatan mempunyai pengaruh positif pada keputusan investasi para Dosen Tetatp Fakultas Ekonomi dan Bisnis Universitas Pembangunan Nasional Veteran Jakarta.

\section{DAFTAR PUSTAKA}

Aminatuzzahra. (2014). Persepsi Pengaruh Persepsi Pengaruh Pengetahuan Keuangan, Sikap Keuangan, Sosial Demografi Terhadap Perilaku Keuangan Dalam Pengambilan Keputusan Investasi Individu (Studi Kasus Pada Mahasiswa Magister Manajemana Universitas Diponegoro). Manajemana Universitas Diponegoro), 23(2), 70-96. https://doi.org/10.14710/jbs.23.2.70-96

Budiarto, A. (2017). Pengaruh Financial Literacy, Overconfidence, Regret Aversion Bias, Danrisk Tolerance Terhadap Keputusan Investasi (Studi pada investor PT. Sucorinvest Central Gani Galeri Investasi BEI Universitas Negeri Surabaya). Jurnal Ilmu Manajemen (JIM), 5(2), 1-9.

Desiyanti, R. (2016). Literasi dan Inklusi Keuangan serta Indeks Utilitas UMKM di Padang. BISMAN Jurnal Bisnis \& Manajemen, 2(2), 122-134.

Dewi, I. M., \& Purbawangsa, I. B. A. (2018). Pengaruh Literasi Keuangan, Pendapatan Serta Masa Bekerja Terhadap Perilaku Keputusan Investasi. E-Jurnal Ekonomi Dan Bisnis Universitas Udayana, 7, 1867. https://doi.org/10.24843/eeb.2018.v07.i07.p04

Fachrudin, K. R., \& Fachrudin, K. A. (2016). The Influence Of Education And Experience Toward Investment Decision With Moderated By Financial Literacy.
Financial Literacy, Behavior, Income and Investment 
Financial Literacy, Behavior, Income and Investment

Polish Journal of Management Studies, 14(2), 51-60. https://doi.org/10.17512/pjms.2016.14.2.05

Fahmi, I. (2015). Manajemen Investasi (Kedua). Salemba Empat.

Fitriarianti, B. (2018). Pengaruh Literasi Keuangan, Perilaku Keuangan Dan Pendapatan Terhadap Keputusan Berinvestasi.

Ghozali, I. (2014). Structural Equation Modeling Metode Alternatif dengan Partial Least Square (4th ed.). Badan Penerbit Universitas Diponegoro.

Hasibuan, B. K., Lubis, Y. M., \& HR, W. A. (2018). Financial Literacy and Financial Behavior as a Measure of Financial Satisfaction. Journal of Economic, Business and Management, 46, 503-507.

Hidayat, T. (2015). Literasi Keuangan. STIE Bank BPD Jateng.

Ismanto, H., \& Dkk. (2019). Perbankan dan Literasi Keuangan (Pertama). DEEPUBLISH.

Khairiyati, C., \& Krisnawati, A. (2019). Analisis Pengaruh Literasi Keuangan Terhadap Keputusan Investasi pada Masyarakat Kota Bandung. Jurnal Manajemen Dan Bisnis, 3(2)

Kholilah, N. Al, \& Iramani, R. (2013). Studi Financial Management Behavior Pada Masyarakat Surabaya. Journal of Business and Banking, 3(1), 69. https://doi.org/10.14414/jbb.v3i1.255

Kumala, A. N., \& Susanti. (2019). Pengaruh Pembelajaran Manajemen Keuangan, Literasi Keuangan, dan Risk Finance Terhadap Perilaku Berinvestasi Mahasiswa Fakultas Ekonomi Universitas Negeri Surabaya. Jurnal Pendidikan Akuntansi. Vol 07, No. 02, 07(02), 197-203.

Larasati, S. (2018). Manajemen Sumber Daya Manusia. DEEPUBLISH.

Noor, J. (2014). Analisis Data Penelitian (Pertama). PT Grasindo.

OJK. (2016). Strategi Nasional Literasi Keuangan Indonesia (Revisit 2016).

Otoritas Jasa Keuangan, 1-99.

Pradikasi, E. (2018). Pengaruh Financial Literacy, Illusion of Control, Overconfidence, Risk Tolerance, dan Risk Perception Terhadap Keputusan Investasi Pada Mahasiswa di Kota Surabaya. Jurnal Ilmu Manajemen (JIM), 6(4), 424-434.a

Pratiwi, N. G., Wahyudi, W., \& Siswantini, T. (2020, January). Analisis Keputusan Investasi Pasar Modal pada Generasi Millennial. In Konferensi Riset Nasional Ekonomi, Manajemen, dan Akuntansi I.

Purwidianti, W., \& Mudjiyanti, R. (2016). Analisis Pengaruh Pengalaman Keuangan Dan Tingkat Pendapatan Terhadap Perilaku Keuangan Keluarga Di

Rasuma Putri, N. M. D., \& Rahyuda, H. (2017). Pengaruh Tingkat Financial Literacy Dan Faktor Sosiodemografi Terhadap Perilaku Keputusan Investasi Individu. EJurnal Ekonomi Dan Bisnis Universitas Udayana, 9, 3407. https://doi.org/10.24843/eeb.2017.v06.109.p09

Sugiyono. (2014). Metode Penelitian Manajemen. Alfabeta.

Sukirno, S. (2016). MAKROEKONOMI Teori Pengantar. Jakarta : Rajawali Pers.

Supriyono,R.,A. (2018). Akuntansi Keperilakuan, Yogyakarta: Gadjah Mada University Press.

Suteja, J., \& Gunardi, A. (2016). Manajemen Investasi dan Portofolio. Bandung: PT Refika Aditama.

Suwardjono. (2018). Teori Akuntansi Perekayasaan Pelaporan Keuangan. Yogyakarta : BPFE-YOGYAKARTA.

Tendelilin, E. (2010). Portofolio danInvestasi (Pertama). KONISIUS.

Yushita, A. (2017). Pentingnya Literasi Keuangan Bagi Pengelolaan Keuangan Pribadi. Jurnal Nominal, VI(1), 11-2 